\section{Islamic Banking and Finance Review}

\section{=IBFR}

\section{Islamic Finance Education: Is There a Misallocation} of Resources Between Curriculum and Academic

\section{Talent?}

\section{Mohamed Aslam Haneef}

Professor, Faculty of Economic and Management Sciences, International Islamic University of Malaysia (IIUM).

moaslam@iium.edu.my

\section{Research Paper Information:}

\section{Jo cite this article}

$\overline{\underline{e}}$

Haneef, M. A. (2018). Islamic finance education: Is there a misallocation of resources between curriculum and academic talent? Islamic Banking and Finance Review, 5, $58-67$.

$\underline{\text { Crossref }}$

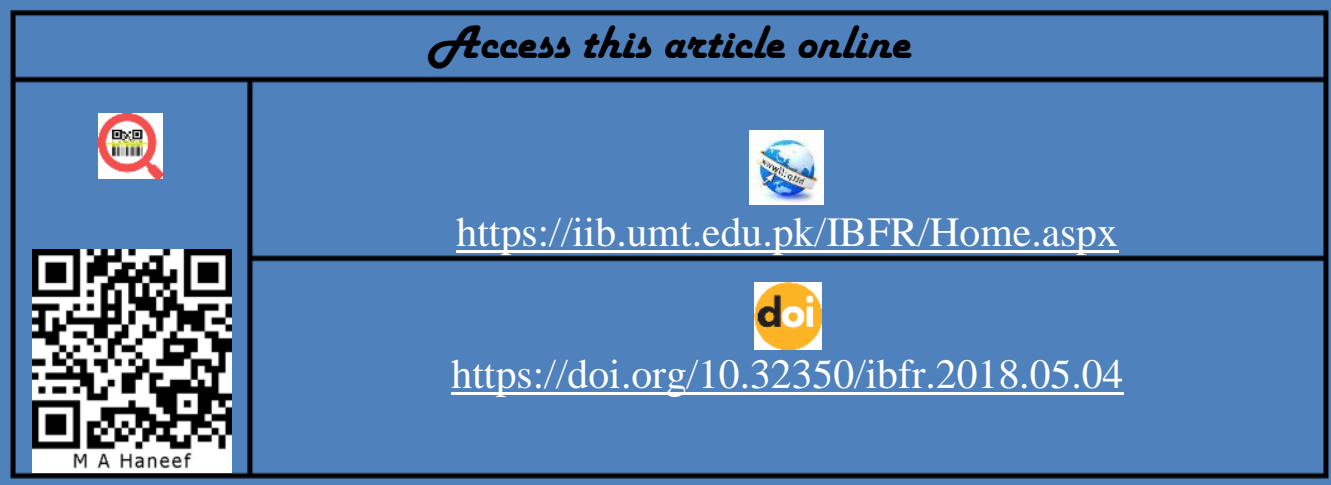

\section{Contact Information}

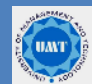

INSTITUTE OF ISLAMIC BANKING (IIB) UNIVERSITY OF MANAGEMENT AND TECHNOLOGY

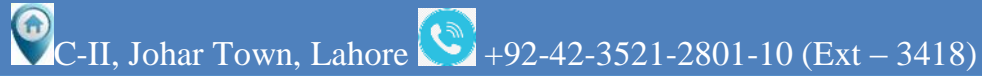

Volume 5

1440-H/ 2018

ISSN (E):

2413-2977

ISSN (P):

2221-5239

\section{Journal do:}

https:|ldoi.org\10.32350libfr

$$
\text { Issue doi }
$$

https://doi.org/10.32350/ibfr.2018.05

Journal i:

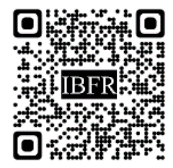

อ

This is an Open Access Journal

Published By

Institute of Islamic Banking

University of Management and Technology (UMT)

3

https://iib.umt.edu.pk/ibfr home.aspx

兽 ibfr@umt.edu.pk

This article is distributed under the terms of Creative Commons Attribution - Share Alike 4.0

International License.

(C) (1) (2)

Attribution-ShareAlike 4.0 International (CC BY-SA 4.0)

\section{Indexing Partner}

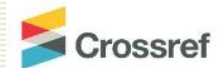

INDEX

IS I A

B) Econli

DRIL

ory of Resear

INDEX COPERNICUS

$R \partial A D=$

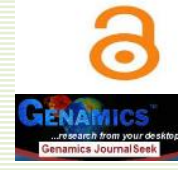

For more detail, click here 


\title{
Islamic Finance Education: Is There a Misallocation of Resources Between Curriculum and Academic Talent?
}

\author{
Mohamed Aslam Haneef ${ }^{1 *}$
}

\begin{abstract}
The numerical global growth rates of Islamic Finance (IF) have been impressive over the last two decades, albeit a slight slow-down in recent years. As a response to this impressive growth rate, Islamic Finance education boomed during the last decade, with the aim of filling the apparent demand for graduates in Islamic Finance. This presentation will shed light on two specific issues. Firstly, what is the actual demand for human resource in Islamic Finance and is there really an excessive demand for Islamic Finance graduates? Secondly, is there a misallocation of resources between curriculum requirements of a standard Islamic Finance curriculum and the structure of academic talent teaching Islamic Finance? The presentation will share findings from the Malaysian Islamic Finance Education Report 2016 that highlights areas of concern. With the tremendous growth of Islamic Finance education in Pakistan in recent years, it is hoped that these findings will lead to a healthy debate about the curriculum structure and human resource planning that should be given serious attention by all stakeholders involved in Islamic Finance education.
\end{abstract}

Keywords: Islamic economics and finance, curriculum, human resource, misallocation

\section{Introduction}

\subsection{Islamic Finance Education in Malaysia}

There is no denying that Islamic economics and finance has seen remarkable growth over the last two decades. The global Islamic financial services industry has grown from a total assets of US dollars 693 million in 2007 to register an overall total assets of US dollars 2.293 trillion by the end of 2016, as reported in the Global Islamic Finance Report $2017^{2}$. The World Bank and the Islamic Development Bank Group's Global Report on Islamic Finance 2017 said that Shariah compliant financial products and services are now offered in 50 Muslim and non-Muslim jurisdictions worldwide. In response to the demand of Islamic

\footnotetext{
${ }^{1}$ Professor, Faculty of Economic and Management Sciences, International Islamic University of Malaysia (IIUM).

${ }^{2}$ This report is published by Edbiz Consulting based in London. Figures vary compared to IFSB 2016 Report putting IBF Assets as approximately USD1.9 trillion. Even if we take the figure to be for 2015, it would not be possible for there to be such a big change in one year.

*Corresponding Author Email: moaslam@iium.edu.my
} 
Finance and hence qualified professionals in the area, education providers have sought to introduce Islamic Finance programs and courses, especially over the period of the last two decades. In a recent study, it was reported that there are currently 533 institutions worldwide offering degrees and courses in Islamic Finance. The UK, Pakistan and Malaysia are leading the education sector, but many issues including curriculum content and qualifications of academics in the area require serious attention ${ }^{3}$.

In Malaysia, the government consulted reports that estimated that the demand for Islamic finance professionals by the year 2020 would be 56,000. As of 2015, it was estimated that graduates from all Malaysian universities having a degree in Islamic finance programs and specializations/courses were approximately 13,000, indicating a worrying shortage. For that purpose, many universities, especially private universities are inclined to introduce programs in Islamic Finance or to offer specializations in Islamic Banking and Finance (IBF) in the conventional finance program of MBA. As of 2016, there were 30 universities offering 95 programs in Islamic Finance and related areas, mostly in public universities.

While Islamic Finance programs are very popular and can be 'income generating' programs, concerned academics should be wary of ensuring that the market surveys done are constantly revisited. It should be noted that quite a few academics and regulators are still questioning the figure of 56,000 graduates given above because it seems rather inflated. In addition, from surveys done over the last three years, it was found that Islamic banking and finance institutions, that is, employers do not necessarily insist on graduates from IBF programs per se. They are quite flexible as the knowledge and skills sought after are quite diverse. Soft skills such as communication skills and ability to work in teams are qualities equally important to employers. As far as knowledge is concerned, there are only so many 'Shari'ah scholars' needed. IBF institutions and the industry would rather have those whose knowledge of banking and finance as well as management skills and experience are sufficient. Hence, it is felt that a more accurate and detailed study of IBF industry's market is needed.

\section{The Role of Education to Produce Qualified Islamic Economists/Bankers ${ }^{4}$}

As mentioned earlier, there has been a proliferation of IBF programs, specializations and courses offered all over the world. This is due to the great demand as a result of the growth in IBF industry. However, any attempt to introduce programs that have Islamic orientation must be carefully planned and

\footnotetext{
${ }^{3}$ Malaysia Islamic Finance Education Report 2016 (MIFER 2016).

${ }^{4}$ For this section, please refer to Haneef (2009) and Haneef (2013).
} 
must have all the resources needed, either these resources are physical, financial or human. With the increasing pressure on university funding, Islamic Finance programs are being introduced without the necessary preparations and resources. Sometimes the content of curriculum does not reflect what is expected of an 'Islamic Finance' program. For example, due to pressure from 'practical industry demand', some IBF programs have neither given sufficient attention to Islamic economics as the 'mother discipline', nor have they given enough attention to the full spectrum of 'Turath' discipline ${ }^{5}$ that provide the Islamic worldview and its constituent elements.

The lack of Islamic economics in these programs has led to criticism that IBF has no Islamic economic base and is founded instead on neoclassical economics. Hence, IBF does not address the goals and objectives of Islamic economics and of the higher objectives of the Shari'ah, but of neoclassical economics that sees profit maximization and maximizing shareholder wealth as its raison d'etre, albeit within the bounds of the Shari'ah (unfortunately misinterpreted and narrowed in meaning to 'Islamic law'). Criticism has turned to cynicism in some cases, leading to some degree of 'disillusionment' with IBF. IBF is likened to a 'tree without its roots', leading to fruits that fail to feed the people on the whole. This is a very serious issue and requires serious attention by all quarters.

As for the Turath courses, Islamic economics/Islamic Banking and Finance programs do offer courses in fiqh and to a lesser extent in ușül al-fiqh, although these courses are taught in ways that are sometimes 'unconnected' to economics/finance. Hence, an extension to the criticism above is that IBF is a mere modern neoclassical economics/finance plus fiqh muamalat but within the existing framework of modern banking. In fact, some leading proponents of IBF say explicitly that the way forward is to have 'Islamic equivalents' to all modern banking and financial instruments. Some of these IBF leaders shun all attempts to concern themselves over 'changing models'. In addition, the level of discourse in methodology and philosophy of science leaves a lot to be desired in these programs. Many Islamic economists and Islamic finance scholars themselves keep referring to the heritage in terms of fiqh and law. An attempt to understand the situation above also brings us to the related issue of human capital challenges faced in providing Islamic economics and IBF curriculum.

A 2016 study by the International Council of Islamic Educators (ICIFE) ${ }^{6}$ looked at the programs, curriculum and talent (lecturers) in Islamic Finance

5 This would include a healthy mix of the study of fiqh and usul al-fiqh, Qur'an and Hadith/Sunnah, Usul al-din and kalam, critical thinking and falsafah and even ethical philosophy and tasawwuf.

${ }^{6}$ Malaysia Islamic Finance Education Report (MIFER) 2016, International Council of Islamic Finance Educators, Kuala Lumpur. 
education in Malaysia. The study covered 19 universities offering IBF education at the Bachelors, Masters and PhD levels, their curriculum and the qualifications of those who were teaching ${ }^{7}$. The three-year study, which in many ways was a first of its kind, not only presented 'numbers' but more importantly, found some interesting facts that show us some of the challenges faced in the educational field and why we have a contemporary IB industry that seems to continue down its current path.

\section{IBF Curriculum Requirement vs. Available Talent: Is There a Mismatch?}

If we review a standard IBF curriculum that has the nomenclature 'Banking and Finance' at the Bachelors level, we would expect the four year program to produce graduates that would be exposed to the knowledge of various aspects related to banking and finance. After analyzing various curricula's structure, for the purpose of this study, any program that wants to provide IBF education would have to have courses in at least the following six domains:

1. Banking and finance

2. Economics

3. Management and marketing

4. Accounting and governance

5. Shari'ah and law

6. Others including truth Islamic

In addition, we would assume that for all categories there is an integrated Islamic-conventional approach, where genuine Islamization of knowledge takes place. For a program to meet the knowledge qualifications in terms of curriculum, we may propose a general curriculum breakdown for IBF as follows,

- Banking and Finance courses- approximately 40-50\% of curriculum

- Economics courses- approximately $10-15 \%$ of curriculum

- Management and Marketing courses- approximately 10-15\% of curriculum

- Accounting and Governance courses- approximately 10-15\% of curriculum

- Shari'ah and Law courses- approximately 10-15\% of curriculum

- Others including quantitative techniques- approximately 10-20\% ICT and turath Islami-

${ }^{7}$ As of January 2018, Ministry of Higher Education sources report that there are 30 Universities having some offering of IBF. Hence ICIFE is currently working on MIFER 2018. 
Next the ICIFE study analyzed the talent (academics) who teach IBF programs. In Malaysia, we have approximately 402 academics from 19 universities whose information was collected by our research team. Some of the findings are summarized below.

1. According to institution, it was found that public universities such as IIUM, UUM, USIM and UM had more than 30 academics in Islamic finance education and made up about $55 \%$ of all academics in IF. Private universities (except for INCEIF) were relatively smaller and less at the forefront of IF education.

2. Of these 402 academics, as far as areas of specialization were concerned, our study collected data from the academics themselves, where academics stated their 'areas of expertise' or specialization according to the domains given earlier. For the purpose of this paper, we focused on the first five domains only and obtained the following results,

- Banking and Finance-

- Economics-

- Management and Marketing-

- Accounting and Governance-

- Shari'ah and Law- approximately $28 \%$

approximately $17 \%$

approximately $14 \%$

approximately $9 \%$

approximately $32 \%$

The above information is presented in the table below:

Table 1

IBF Curriculum Requirement vs. Available Talent

\begin{tabular}{|c|c|c|c|}
\hline Domain\\
% & $\%$ of curriculum & $\%$ of academics & Implications \\
\hline Banking and Finance & $40-55 \%$ & $28 \%$ & $\begin{array}{l}\text { Seriously under } \\
\text { represented }\end{array}$ \\
\hline Economics & $10-15 \%$ & $17 \%$ & $\begin{array}{l}\text { Slightly over } \\
\text { represented }\end{array}$ \\
\hline $\begin{array}{l}\text { Management and } \\
\text { Marketing }\end{array}$ & $10-15 \%$ & $14 \%$ & Well represented \\
\hline $\begin{array}{l}\text { Accounting and } \\
\text { Governance }\end{array}$ & $10-15 \%$ & $9 \%$ & $\begin{array}{l}\text { Slightly under- } \\
\text { represented }\end{array}$ \\
\hline Shari'ah and Law & $10-15 \%$ & $32 \%$ & $\begin{array}{l}\text { Seriously over } \\
\text { represented }\end{array}$ \\
\hline
\end{tabular}




\section{Findings and Implications}

What the above lists show clearly is that our talent (academics) seems to be misaligned with the requirements of curriculum. One would have thought that an IBF curriculum with the nomenclature 'banking and finance' should be primarily taught by academics who have knowledge of banking and finance (albeit with an Islamic banking and finance orientation through genuine Islamization of knowledge). Instead, what we seem to have in the Malaysian case is an over representation of academics from the Shari'ah and law fields. Many of these academics have very little or no knowledge in banking and finance as far as formal academic background is concerned. Most, if not all, may not have taken any basic courses in statistics and mathematics for economics/finance. Hence the question we have to ask is 'what are our Islamic banking and finance students being taught in the curriculum'?

This situation is compounded when we look into the figures in greater detail.

a. Although the fifth domain is termed Shari'ah and law, in the Malaysian case we found that the majority of the courses offered in IBF programs are related to Islamic law/figh and academics teaching these courses are from the Islamic law background, that is, figh (and some with usul al-figh). In most universities, one may be hard-pressed to find even one or two academics from the 'law' side. Hence, what is being taught is not the existing BF and IBF legal frameworks of the country, but very much classical contracts that very rarely have any real locus standi in the legal systems that govern the banking and finance activities today? What is taught more often than not is the interpretation of some modern scholars of the 'classical scholars'; almost always these have to be 'blended' and modified if they are to be used in developing the instruments of IBF today, if they are used in the national legal codes at all. It is imperative that the scholars in this domain have sufficient knowledge of contemporary laws that govern banking and finance in a jurisdiction, better still in many jurisdictions.

b. When we look at the background of those who claim to have Islamic banking and Islamic economics specializations, we actually have academics whose first and even second degrees are in Shari'ah or Islamic law. Some may have done a PhD in Islamic Banking or Islamic economics (especially in Islamic commercial contracts) and quite a number have done it by research only (in UK or programs that have a thesis only option). As mentioned earlier, these academics may have never taken a course in modern economics and finance. However, because their $\mathrm{PhD}$ is in Islamic commercial contracts or in some legal aspect of Islamic banking, they 
claim IBF or Islamic economics as their area of specialization. A more appropriate phrase for these scholars' specialization should be fiqh related aspects of commerce/banking' rather than Islamic Banking itself. In fact, universities should apply a more stringent criterion for designating one's expertise, including one's educational background, recent publications and research rather than leaving it to the individual academic to claim his/her specialization!

c. If we're-designated' domains based on (b) above, this would probably involve another $30 \%$ of those who now claim to be in the domains of banking and finance and economics to actually be re-designated to the Shari'ah domain! Hence, what this means is that the number of Shari'ah (Islamic law) academics would be even higher than the $32 \%$ stated (maybe going up to about $40 \%$ ), while those in the domains of economics and banking and finance would go down.

d. With this finding, it is not surprising that the Turath component of IBF curricula are 'overly Islamic law centric', while other areas of the Turath are not given sufficient attention. It also confirms the view that some employers are unhappy with the level of banking and finance knowledge and skills of their IBF graduates! Much more analysis is needed of the data and greater discussion and debate is needed to chart out the future of IBF education. No one should feel offended as the intention is to ensure that IBF programs are of the highest quality.

e. It is also very important to stress here that curricula should also take into consideration what the industry requires. If the nomenclature of the degree is 'Islamic Banking and Finance', it is important to ensure that graduates understand modern banking and finance in both theory and practice, and both from the descriptive and analytical dimensions. This includes the minimum level of technical and quantitative techniques needed to understand modern banking and finance. Hence, IBF graduates must be banking and finance graduates and not sub-standard fiqh scholars. For those who wish to focus on aspects of Islamic law, they need to take Islamic law degrees. These Islamic law degrees could have some minor subjects in Islamic economics, and/or Islamic banking. However, the number of these graduates may be minimal for the IBF industry as the number of people required to sit on Shari'ah boards is very limited!

f. The above two issues ( $\mathrm{d}$ and e) also depict a 'mind-set' problem that promotes, ironically, a secular mind-set! By interpreting the Shari'ah as 
primarily law and by observing the heritage as confined to fiqh, and since the basis of these are Qur'an and sunnah, other areas of life such as economics and finance are somehow seen as 'this worldly' hence less Islamic. Thus, ulama' are those with Islamic law degrees, while those who study Islamic economics or Islamic Banking and Finance (with all the requirements of an integrated curriculum) are relegated to being just economists and bankers rather than in any way being those who possess 'ilm' and are appropriately categorized as 'ulama'. Worse still, there is a perceived hierarchy of knowledge and scholars, where those in 'worldly' sciences are somehow less qualified and 'less important' than those with pure Islamic law qualifications. What is central is to have knowledge of the Shari'ah (Islamic law) and then all issues in IBF will be resolved.

g. Contrary to this simplistic view, the shari'ah in its original form means 'total guidance'. By limiting its meaning to Islamic law is to betray the symptoms of a disease identified by Prof. Al-Attas more than 30 years ago as 'corruption of knowledge'. On the contrary, the Shari'ah is much wider than law and includes all principles, norms, values and ethical guidelines that govern all aspects of life, including the specific rituals as well as our dealings with family, society, nation, and nature. Shari'ah is founded in the primary sources of Islamic knowledge, that is, the revelation. The ability to see the Shari'ah in this holistic way will treat all aspects of life as potential forms of 'ibadah' or worship if they are done with correct intention, knowledge and action. 


\section{Lessons Learnt and Concluding Remarks}

The Malaysian case of Islamic finance education provides some lessons for others, both positive and other-wise. While there is no doubt that Malaysia is one of the major players in the contemporary IBF industry and in Islamic finance education, Pakistan has its own context. However, some suggestions are given below.

a. A thorough study of the whole spectrum of Islamic Finance education should be carefully and professionally conducted just as the one conducted in Malaysia that probed comprehensively across three dimensions including programs and market demand and supply, curriculum development and academic talent. The purpose should be to critically analyze the situation and not to over-exaggerate the success of IBF and refusal to acknowledge its weaknesses.

b. Before any new programs are introduced, it is necessary to make sure that the existing ones are serving the genuine needs of the market, rather than over doing the 'income earning' pressure that IBF programs can deliver.

c. Islamic Finance should serve the genuine needs of the development of a nation. The outdated 'shareholder theory' has to be replaced with the innovative stakeholder theories in economic decision-making, augmented by reference to the higher objectives of the Shari'ah.

d. As far as talent and curriculum are concerned, in-house training, crossdiscipline education as well as long-term human resource planning is greatly needed. Where there are shortages, working together with capable partners and sharing of resources is the only way forward. 


\section{References}

EDBIZ Consulting. (2017). Global Islamic finance report 2017. London: Author.

International Council of Islamic Finance Educators. (2016). Malaysia Islamic finance education Report 2016 (MIFER 2016). Kuala Lumpur: Author.

Haneef, M. A. (2009). Islamic banking and finance in the $21^{\text {st }}$ century: Selected issues in human capital development. Islam and Civilizational Renewal, 1(2), 292-302.

Haneef, M. A. (2013). Teaching of economics at IIUM: The challenges of integration and Islamization. In Mohd. Nizam Barom et al. (Ed.). Islamic economics education in Southeast Asian universities. Kuala Lumpur: Centre for Islamic Economics, International Islamic University Malaysia.

World Bank, \& Islamic Development Bank Group. (2017). Global report on Islamic finance: Islamic finance - A Catalyst for Shared Prosperity? Washington, DC: World Bank. 